\title{
Nursing care with surgical arteriovenous shunt in renal dialysis: a validation study
}

\author{
Cuidado de enfermagem com a derivação arteriovenosa cirúrgica na diálise renal: estudo de validação \\ Cuidado de enfermería con la derivación arteriovenosa quirúrgica en la diálisis renal: estudio de validación
}

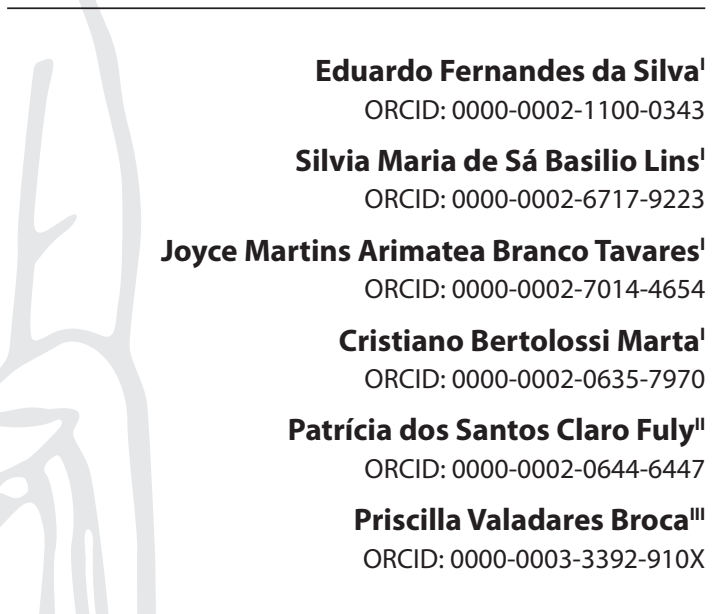

'Universidade do Estado do Rio de Janeiro. Rio de Janeiro, Rio de Janeiro, Brazil. "Universidade Federal Fluminense. Niterói, Rio de Janeiro, Brazil.

I'Universidade Federal do Rio de Janeiro. Rio de Janeiro, Rio de Janeiro, Brazil.

How to cite this article:

Silva EF, Lins SMSB, Tavares JMAB, Marta CB, Fuly PSC, Broca PV. Nursing care with surgical arteriovenous shunt in renal dialysis: a validation study. Rev Bras Enferm. 2020;73(6):e20190012. doi: http://dx.doi.org/10.1590/0034-7167-2019-0012

Corresponding author:

Eduardo Fernandes da Silva

E-mail: eduardofsilva.enf@gmail.com

EDITOR IN CHIEF: Dulce Aparecida Barbosa ASSOCIATE EDITOR: Mitzy Reichembach

\begin{abstract}
Objectives: to validate a care protocol for the monitoring and prevention of arteriovenous fistula complications. Methods: a validation methodological study with a quantitative approach, developed in a university hospital in the city of Rio de Janeiro. Results: scientific evidence was gathered from 20 researches. A care protocol was developed, composed of 15 items and divided into 3 sessions. The protocol was validated by a group of 11 experts, obtaining a content validity index of 0.95 . Conclusions: the protocol proposes nursing care capable of preventing and monitoring arteriovenous fistula complications, punctured with a traditional technique, taking into account the actions implemented from patients' entry into the machine until the end of therapy.

Descriptors: Arteriovenous Shunt, Surgical; Renal Dialysis; Nurse's Role; Nursing Care; Nephrology Nursing
\end{abstract}

\section{RESUMO}

Objetivos: validar um protocolo assistencial para monitoramento e prevenção de complicações de fístula arteriovenosa. Métodos: estudo metodológico de validação com abordagem quantitativa, desenvolvido em um hospital universitário do Rio de Janeiro. Resultados: foram extraídas evidências científicas de 20 pesquisas. Foi elaborado um protocolo assistencial composto por 15 itens divididos em 3 sessões. O mesmo foi validado por um grupo de 11 especialistas, obtendo um índice de validade de conteúdo de 0.95 . Conclusões: o protocolo propõe cuidados de enfermagem capazes de prevenir e monitorar as complicações da fístula arteriovenosa, puncionada com técnica tradicional, levando em consideração as ações implementadas desde a entrada do paciente na máquina até o final da terapia.

Descritores: Derivação Arteriovenosa Cirúrgica; Diálise Renal; Papel do Profissional de Enfermagem; Cuidado de Enfermagem; Enfermagem em Nefrologia.

\section{RESUMEN}

Objetivos: validar un protocolo asistencial para monitoreo y prevención de complicaciones de fístula arteriovenosa. Métodos: estudio metodológico de validación con abordaje cuantitativo, desarrollado en un hospital universitario de la cuidad de Río de Janeiro. Resultados: se extrajeron evidencias científicas de 20 encuestas. Fue elaborado un protocolo asistencial compuesto por 15 ítems divididos en 3 sesiones. El protocolo fue validado por un grupo de 11 expertos, obteniendo un índice de validez de contenido de 0.95 . Conclusiones: el protocolo propone cuidados de enfermería capaces de prevenir y monitorear las complicaciones de la fístula arteriovenosa, puncionada con técnica tradicional, tomando en consideración las acciones implementadas desde la entrada del paciente en la máquina hasta el final de la terapia.

Descriptores: Derivación Arteriovenosa Quirúrgica; Diálisis Renal; Rol de la Enfermera; Atención de Enfermería; Enfermería en Nefrología. 


\section{INTRODUCTION}

Chronic kidney disease is considered a major public health problem worldwide as it causes high morbidity and mortality rates in addition to the negative impact on a person's quality of life. The estimated Brazilian prevalence and incidence rate of patients under dialysis is 610 per million population (pmp) and 193 pmp, respectively ${ }^{(1)}$.

One in ten adults suffer from chronic kidney problems and $60 \%$ of these people are unaware that they have the problem ${ }^{(1)}$. Generally, patients seek medical help when the disease is at an advanced stage, close to the need for dialysis. In Brazil, the estimated number of dialysis patients was 126,583 in 2017. Of these, $117,722(93.1 \%)$ used dialysis as a therapeutic modality and $79.5 \%$ used arteriovenous fistula (AVF) as vascular access ${ }^{(1)}$.

Of the hospitalizations of patients under dialysis, $25 \%$ are related to complications with AVF. Thrombosis is a major cause of loss of this venous access, present in $80 \%$ of fistulas ${ }^{(2)}$. Its occurrence is usually preceded by hypotension, vessel narrowing, decreased blood flow, repeated punctures at the same site, bruising and bleeding. These factors provide the formation of a thrombus, which can be avoided as long as some precautions are taken. In addition to this complication, there is also stenosis, ischemic steal syndrome (hand or forearm ischemia) infections and pseudoaneurysm ${ }^{(2-3)}$.

Often these complications may occur due to inadequate techniques adopted in nursing procedures associated with the absence or precariousness of a continuing education program for professionals. One of the duties of the dialysis center's technical manager is to ensure periodic training for the nursing staff, supporting AVF complications monitoring and prevention ${ }^{(2-3)}$.

AVF care is the responsibility of both patients and health teams. Nurses, however, because of their proximity to patients, have the responsibility to remain vigilant regarding possible signs of vascular access complications. In 2018, a new Ordinance of chronic kidney patient care was published that changed nurses/ patients ratio from $1 / 35$ to $1 / 50$. Therefore, having care protocols is fundamental in contributing to a safe care practice ${ }^{(4)}$.

\section{OBJECTIVES}

To validate a care protocol for AVF complications monitoring and prevention.

\section{METHODS}

\section{Ethical aspects}

The development of the study complied with Resolution No. 466 of December 12, 2012, of the Brazilian National Health Board (CNS - Conselho Nacional de Saúde)/Ministry of Health (MoH). This Resolution, through its legal competences, establishes guidelines and norms that regulate research involving human beings. The research was approved by the Research Ethics Committee of Hospital Universitário Pedro Ernesto (HUPE) with the following in CAAE (Certificado de Apresentação para Apreciação Ética - Certificate of Presentation for Ethical Consideration) No. 82801417.0.0000.5259.

\section{Design, period and place of study}

This is a validation methodological research with quantitative approach guided by the SPIRIT tool. Data collection took place from August to October 2018 and had as an "anchor" space for one-to-one contact with participants, the nephrology department of Hospital Universitário Pedro Ernesto, located in Rio de Janeiro/RJ.

\section{Population or sample; inclusion and exclusion criteria}

The study included 11 expert judges in the field, including doctors and nurses. Inclusion criteria were: minimum experience of five years in dialysis room. The exclusion criterion was: professionals who were on vacation or work leave for any reason. The sample was non-probabilistic for convenience, meeting the minimum recommendation of six and maximum of twenty experts for content validation ${ }^{(5)}$.

\section{Study protocol}

The study was conducted in two stages, the first being an integrative literature review ${ }^{(6)}$ to choose the guidelines and conduct of professional nurses in AVF complications monitoring and prevention. In the second stage, these guidelines were validated. The protocol was built by searching the databases with analysis of works published between 2007 and 2016 in Portuguese, English and Spanish.

We used the searches available in the LILACS databases through the portal VHL, and MEDLINE through the portal PUBMED. In the advanced search for MEDLINE the descriptors in English "Surgical Arteriovenous Shunt" and "Renal Dialysis" were crossed and used. In LILACS, the descriptors in Portuguese "Derivação arteriovenosa cirúrgica" AND "Diálise renal" were crossed and uses. Free, fully available papers that answered the following research question were included: "What nursing care is required to prevent and monitor AVF complications with traditional puncture technique during the dialysis session?" Duplicate studies in the databases that described the surgical procedure, preoperative care, as well as care performed by patients at home were excluded.

Search in the LILACS database presented 46 articles. Filters for search were activated and there were 11 articles left. Of which 3 met the inclusion criteria after analyzing the titles and abstracts. In MEDLINE, there were 5,769 articles. Filters for search were activated and there were 438 articles left. Of these, 17 met the inclusion criteria for the study after analyzing titles and abstracts.

A total of 20 articles were considered, summing the two databases. Most of the excluded studies approached surgical and preoperative procedures, thus leaving few works that fit the scope of the proposed study. From the reading of these articles, evidence that supported the nursing care proposed in AVF complications monitoring and prevention protocol was extracted.

After protocol construction, participants were verbally invited to the "anchor" unit of the study. All judges received the following materials: two copies of the informed consent form and one copy of the protocol for completion at their home or place of their choice, and upon completion, they were returned to the researcher. 
The organization of the tool was divided into participant identification, completion guidance and 15 nursing care items, divided into three sessions to monitor and prevent AVF complications, with Likert scale. A space was also provided for judges' suggestions and comments if they deemed it necessary.

\section{Analysis of results, and statistics}

The analysis of the results involved gathering the studies selected by the integrative review performed. From these we extracted the scientific evidence pertinent to the research theme, being condensed in the formulated protocol. Nursing care that reached a content validity index $(\mathrm{CVI})$ of $\geq 0.80$ was considered valid ${ }^{(5)}$.

CVI measured the proportion or percentage of judges who agreed on the tool items. It allowed to analyze each of the 15 items individually and then the tool as a whole by means of a Likert scale with a score of one to four. In the constructed tool, it was established to assess the relevance of each item: 1 - not relevant; 2 - little relevant; 3 - relevant and 4 - highly relevant.

The index score was calculated by summing the agreement of items answered by " 3 " or "4" by experts. Items "1" and "2" were eliminated. After obtaining the number of answers " 3 " and " 4 " of each item individually, the sum of this value was divided by the total number of answers obtained. The final value of the tool's
CVI was calculated by summing the CVI of each item and dividing by the total number of items.

\section{RESULTS}

Of the 20 articles used, six were national and 14 international. 15 were quantitative, two were qualitative and three were integrative reviews. Regarding the level of evidence, six studies were level VI, three studies were level V and 11 studies were level IV ${ }^{(7)}$. Of the research with level of evidence IV, nine were retrospective cohort studies and two were prospective cohorts.

The elaborated protocol considers the traditional technique of AVF puncture. It consists of 15 items, each one subdivided into three sessions: What to do? What to observe? What am I preventing? The sequence of items obeyed the logic of care required from the moment the professional receives patients in dialysis room until the end of the session. The nursing care proposed is presented in the Chart 1.

For content validation, the tool was submitted to a sample of 11 expert judges, of which ten are nurses and one doctor; eight are women and three men. An average of 19 years of training, ranging from eight to 33 years, and an average length of experience in dialysis room of 12.9 years, ranging from five to 33 years. Judges assessed CVI according to the Table 1.

Chart 1 - Nursing care for arteriovenous fistula complications monitoring and prevention

\begin{tabular}{|c|c|c|c|}
\hline \multirow[b]{2}{*}{ ITEMS } & \multicolumn{3}{|c|}{ STAGES } \\
\hline & What to do? & What to observe? & $\begin{array}{l}\text { What am I } \\
\text { preventing? }\end{array}$ \\
\hline Item 1 & - To make sure patients have washed the $\operatorname{arm}^{(2)}$ & - Correct arm washing. & Infection \\
\hline Item 2 & $\begin{array}{l}\text { - To perform AVF inspection and antisepsis and } \\
\text { assess the rest of the arm, shoulder, breast, neck and } \\
\text { face }{ }^{(8-10)} \text {. } \\
\text { - To record the presence of edema or collateral veins } \\
\text { in any of these areas }{ }^{(8-10)} \text {. } \\
\text { - To perform the rapid examination of arteriovenous } \\
\text { access through tests such as: pulse increase test } \\
\text { and arm lift test. Pulse increase test performed } \\
\text { with complete access occlusion several centimeters } \\
\text { beyond arterial anastomosis and pulse strength } \\
\text { assessment; Arm lift test: performed by arm lift and } \\
\text { examination of normal collapse of an AVF(9). }\end{array}$ & $\begin{array}{l}\text { - If there are dirt or signs of infection. } \\
\text { - Presence of edema and collateral veins. } \\
\text { - In the pulse increase test, it is considered normal when } \\
\text { there is a pulse increase in the upstream (arterial) part of } \\
\text { the finger occlusion. } \\
\text { - Usually when we occlude the exit of an arteriovenous } \\
\text { access, we have two effects: fremitus disappears or the } \\
\text { part of the upstream (arterial) access to the finger should } \\
\text { become hyperpulsable. If the fremitus persists, suspect an } \\
\text { accessory outlet. } \\
\text { - Arm lift test is abnormal when the fistula becomes "full" } \\
\text { after arm lift and there is no collapse, an indication of } \\
\text { downstream (outflow or "venous") stenosis. }\end{array}$ & $\begin{array}{l}\text { Infection } \\
\text { Stenosis }\end{array}$ \\
\hline Item 3 & $\begin{array}{l}\text { - To perform palpation of } \operatorname{AVF}^{(2)} \text {. } \\
\text { - To auscultate AVF(2). }\end{array}$ & $\begin{array}{l}\text { - Perception of fremitus and murmur. } \\
\text { - Normality presents with a soft pulse, i.e., the pressure } \\
\text { necessary to interrupt the pulsations is small. } \\
\text { - Normality of the fremitus resembles a "tinnitus" that can } \\
\text { be palpated with the fingers continuously. } \\
\text { - Intermittent fremitus suggests arterial stenosis. } \\
\text { - Auscultation assesses the quality of the blow. It enables } \\
\text { detection and localization of a stenosis by assessing the } \\
\text { continuity or intermittence of the murmur. }\end{array}$ & $\begin{array}{l}\text { Stenosis } \\
\text { Thrombosis }\end{array}$ \\
\hline Item 4 & $\begin{array}{l}\text { - To choose needle gauge according to vein size, } \\
\text { maturity and volume to be reached } \\
\text { - To start use of AVF ( } 1^{\text {st }} \text { use) with smaller needle } \\
\text { gauge }{ }^{(8)} \text {. } \\
-17 \mathrm{G}-250 \mathrm{ml} \mathrm{flow}^{(8)} \text {. } \\
\text { - } 16 \mathrm{G}-350 \mathrm{ml} \mathrm{flow}^{(8)} \text {. } \\
\text { - To access more mature AVF with larger needle } \\
\text { gauge }{ }^{(8)} \text {. } \\
-15 \mathrm{G}->350 \mathrm{ml} \mathrm{flow}^{(8)} \text {. }\end{array}$ & $\begin{array}{l}\text { - If the chosen needle matches the prescribed blood flow } \\
\text { volume and vessel maturity. } \\
\text { - Rule of six: a mature AVF should follow the "rule of } 6 \text { " - } \\
\text { should be } 6 \mathrm{~mm} \text { in diameter, be less than } 6 \mathrm{~mm} \text { below the } \\
\text { skin, have a minimum blood flow of } 600 \mathrm{ml} / \mathrm{min} \text { and have } \\
\text { a straight cannulation segment minimum } 6 \mathrm{~cm} \text {. Maturation } \\
\text { generally should occur around six weeks after surgery. }\end{array}$ & $\begin{array}{c}\text { Thrombosis } \\
\text { Pseudoaneurysm }\end{array}$ \\
\hline
\end{tabular}




\begin{tabular}{|c|c|c|c|}
\hline \multirow[b]{2}{*}{ ITEMS } & \multicolumn{3}{|c|}{ STAGES } \\
\hline & What to do? & What to observe? & $\begin{array}{l}\text { What am I } \\
\text { preventing? }\end{array}$ \\
\hline Item 5 & $\begin{array}{l}\text { - To avoid repeating the previous puncture site }{ }^{(8,12)} \text {. } \\
\text { - To maintain a space of } 3 \text { (three) centimeters from the } \\
\text { anastomosis site for the arterial puncture and for the } \\
\text { venous to maintain a space of } 5 \text { (five) centimeters in } \\
\text { relation to the arterial }{ }^{(8,12)} \text {. }\end{array}$ & $\begin{array}{l}\text { - Vessel dilation, skin thickness and bleeding time after } \\
\text { puncture. } \\
\text { - Normal bleeding time: approximately } 10 \text { to } 15 \text { minutes } \\
\text { - Excessive bleeding after puncture:> } 20 \text { minutes. } \\
\text { - If the needles are too close. } \\
\text { - If the space between them is being respected. }\end{array}$ & Pseudoaneurysm \\
\hline Item 6 & - Do not puncture eroded, reddened or injured areas ${ }^{(8,11-12)}$. & - If the chosen area shows any of these signs. & Infection \\
\hline Item 7 & $\begin{array}{l}\text { - To turn the needle bevel after puncturing } \\
\text { downward, allowing full access channeling and to } \\
\text { minimize post-puncture bleeding }{ }^{(3,13)} \text {. }\end{array}$ & - If positioning is in agreement and proper flow. & Pseudoaneurysm \\
\hline Item 8 & $\begin{array}{l}\text { - To ensure needle attachment following unit } \\
\text { protocol }^{(14)} \text {. }\end{array}$ & $\begin{array}{l}\text { - If the fixing is adequate. } \\
\text { - If the needle is too far out. }\end{array}$ & Pseudoaneurysm \\
\hline Item 9 & $\begin{array}{l}\text { - To check correct channeling and permeability of } \\
\text { vascular access with a syringe and saline } \mathrm{e}^{(2)} \text {. } \\
\text { - To connect patient to cardiopulmonary bypass after } \\
\text { verification }^{(2)} \text {. }\end{array}$ & - If there is proper flow. & Thrombosis \\
\hline Item 10 & $\begin{array}{l}\text { - To pay attention to monitoring vital signs, especially } \\
\text { blood pressure }{ }^{(2,8,12)} \text {. }\end{array}$ & - Alteration of vital signs. & Thrombosis \\
\hline Item 11 & $\begin{array}{l}\text { - Remove the needle if hematoma or blood leakage } \\
\text { occurs at the time of puncture and do not manipulate } \\
\text { the puncture site }{ }^{(12,15)} \text {. } \\
\text { - To compress the site to hemostasis }{ }^{(12,15)} \\
\text { - To perform cold compress on site }{ }^{(15)} \text {. }\end{array}$ & - Signs of extravasation or local hematoma. & $\begin{array}{l}\text { Pseudoaneurysm } \\
\text { Thrombosis }\end{array}$ \\
\hline Item 12 & $\begin{array}{l}\text { - To monitor hemodynamic parameters during dialysis } \\
\text { session, such as access flow, blood circuit flow and } \\
\text { dynamic pressures; Pre-pumping blood pressure: }-80 \text { to } \\
-200 \mathrm{mmHg} \text {, should not exceed } \\
-250 \mathrm{mmHg}\left({ }^{(10)} \text {. }\right. \\
\text { - To check circuit venous pressure: always positive value. } \\
\text { Ideal is between } 50 \text { and } 250 \mathrm{mmH} \text {. Increased venous } \\
\text { pressure means that access is with problems such as } \\
\text { recirculation of the fistula that worsens the quality of } \\
\text { dialysis and increases the risk of thrombosis }{ }^{(10)} \text {. }\end{array}$ & $\begin{array}{l}\text { - If there is anything outside the parameter. } \\
\text { - Normal operation of the dialysis machine. }\end{array}$ & $\begin{array}{l}\text { Stenosis } \\
\text { Thrombosis }\end{array}$ \\
\hline Item 13 & $\begin{array}{l}\text { - To reposition the needle or perform a new } \\
\text { puncture in case of (arterial) inflow, characterized by } \\
\text { insufficient blood supply to the pump, as the needle } \\
\text { may be attached to the vessel wall(2,12,16). }\end{array}$ & $\begin{array}{l}\text { - Whether the supplied flow is being adequate. } \\
\text { - Gauge of the chosen needle compatible with access. }\end{array}$ & Thrombosis \\
\hline Item 14 & $\begin{array}{l}\text { - To carefully remove the needle at the end of the } \\
\text { session } \\
\text { - To wait for a minimum hemostasis time of } 10 \text { to } \\
15 \text { minutes or until a stable clot is formed at the } \\
\text { puncture site }{ }^{(2,8,12)} \text {. }\end{array}$ & $\begin{array}{l}\text { - If there was blood leakage. } \\
\text { - Excessive bleeding (> } 20 \text { minutes). } \\
\text { - A bleeding for more than twenty minutes may be related } \\
\text { to the amount of anticoagulant and antihypertensive. } \\
\text { - Emergence of hematoma. }\end{array}$ & $\begin{array}{l}\text { Thrombosis } \\
\text { Pseudoaneurysm }\end{array}$ \\
\hline Item 15 & $\begin{array}{l}\text { - To perform dressing with light compression, with } \\
\text { gauze, for approximately five minutes, with tape and } \\
\text { gauze after complete hemostasis }{ }^{(12,17)} \text {. } \\
\text { - To advise patients to be removed only six hours after } \\
\text { the end of dialysis, guiding them to be kept dry and } \\
\text { clean }^{(12,17)}\end{array}$ & $\begin{array}{l}\text { - Whether the dressing stays clean until the moment } \\
\text { patients are in the environment. } \\
\text { - In case of extravasation, change the dressing after new } \\
\text { hemostasis. }\end{array}$ & Infection \\
\hline
\end{tabular}

Note: AVF - arteriovenous fistula.

From the analysis of the exposed situation, it is observed that only item seven obtained a score below what is expected $(0.63$ $<0.80$ ). This means that it is not relevant for validation, leading to a question about this conduct by nursing professionals in preventing AVF complications. All other items obtained satisfactory results. Protocol's final CVI was considered excellent at 0.95 .

In the space for comments and suggestions of experts, we obtained some contributions in each item according to the experience and experience of each. Suggestions were grouped around the same theme and added to the final version of the protocol. They were accepted only when they were strictly related to the proposed protocol.
Table 1 - Content Validity Index of arteriovenous fistula complications monitoring and prevention protocol items

\begin{tabular}{cccccc}
\hline ITEM & CVI & ITEM & CVI & ITEM & CVI \\
\hline 1 & 1.0 & 6 & 1.0 & 11 & 1.0 \\
2 & 1.0 & 7 & 0.63 & 12 & 1.0 \\
3 & 0.9 & 8 & 1.0 & 13 & 1.0 \\
4 & 1.0 & 9 & 0.81 & 14 & 1.0 \\
5 & 1.0 & 10 & 1.0 & 15 & 1.0 \\
& & TOOL'S FINAL CVI $=0.95$ & & \\
\hline
\end{tabular}

Note: CVI - Content Validity Index; AVF - arteriovenous fistula. 
Chart 2 - Experts' suggestions on arteriovenous fistula complications monitoring and prevention

\begin{tabular}{|c|l|}
\hline ITEM & \multicolumn{1}{c|}{ COMMENT/SUGGESTION } \\
\hline 1 & - Patient guidance on arm washing (What to do?) \\
\hline 2 & - Observation of distal cyanosis (What to do?) \\
\hline 5 & - Blood recirculation (What am I preventing?) \\
\hline 7 & - Hematoma (What am I preventing?) \\
\hline 8 & $\begin{array}{l}\text { - Preference for puncture with bevel down when possible } \\
\text { (What to do?) }\end{array}$ \\
\hline 9 & - Hematoma (What am I preventing?) \\
\hline 11 & - Hematoma (What am I preventing?) \\
\hline 15 & - Gauze change only if it is visibly soiled (What to do?) \\
\hline
\end{tabular}

\section{DISCUSSION}

Dialysis center nurses play a central role in preventing AVF complications. Their functions range from patient guidance on arm washing to performing an accurate physical examination. Washing the limb with pre-puncture AVF ensures the removal of dirt and transient microbiota, and with the aid of an antiseptic, reduces the microbiota residing in this limb, reducing infection risk ${ }^{(8)}$.

AVF physical examination comprises a set of procedures to be performed, such as observation, palpation and auscultation. This allows nurses to perform an assessment of the access member to obtain a set of objective and subjective information, thus preventing complications related to vascular access ${ }^{(8)}$. In addition, examination should not be limited to the site of arteriovenous access. The rest of the arm, neck, breast, shoulder, and face should be included, as the edema that may be present in any of these areas leads to a suspicion of downstream stenosis in this access ${ }^{(11)}$.

The choice of needle gauge according to access maturity, duration of use and the flow provided should also be verified by the nursing staff as improper use can harm access and impair dialysis efficiency ${ }^{(11)}$. A mature AVF should follow the "rule of six", i.e., $6 \mathrm{~mm}$ in diameter, be less than $6 \mathrm{~mm}$ below the skin and have a minimum blood flow of $600 \mathrm{ml} / \mathrm{min}^{(11-12)}$. Another study, however, considered fistulas larger than $4 \mathrm{~mm}$ and allowing blood flow greater than 250 to $500 \mathrm{ml} / \mathrm{min}$ to be mature from ultrasound criteria ${ }^{(13)}$.

There is no universally accepted method for cannulation of AVF. Most authors suggest changing the puncture sites at each dialysis, thus allowing better healing of the puncture wound and reducing complications such as hematoma, dilation, stenosis, infection, and pseudoaneurysm formation ${ }^{(12)}$. Repeated puncture in the arteriovenous access weakens the fistula wall and leads to the appearance of aneurysms, explaining the importance of rotating the needle insertion sites. The insertion method affects patency and long-term access survival(13).

Another relevant aspect is the vigilance regarding the space between the arterial and venous needles, preventing blood recirculation and low efficiency dialysis. Turning by $180^{\circ}$ around the axis itself, after insertion of the needle, in order to obtain a full access channel and reduce the risk of bleeding, is recommended in literature, but there was no systematic study on this procedure and no is agreement among professionals ${ }^{(2,8)}$.

Correct checking of vascular access channeling and permeability with a syringe and saline is recommended since return of blood is not sufficient proof of correct needle position. The "wet needle" technique uses saline in the attached syringe to irrigate the needle, and if there is infiltration, the saline causes less damage to tissues adjacent to the AVF. It also prevents blood leakage when using dry needles for cannulation or when removing the cap to let air out of the needle. Removing the cap also increases the risk of exposing dialysis staff and patients to blood leakage ${ }^{(13)}$.

Monitoring of vital signs and hemodynamic parameters during dialysis session assists in detecting possible access dysfunctions. Hypotension predisposes to clot formation and increases the risk of decreased blood flow. Increased venous pressure may indicate fistula recirculation problems worsening dialysis quality and increasing the risk of thrombosis ${ }^{(2,14)}$. Eroded, reddened or bruised areas should not be punctured to promote skin integrity ${ }^{(14)}$.

In cases of hematoma or bleeding, removal of the needles, slight compression of the site for at least 10 minutes and cryotherapy are indicated ${ }^{(12)}$. Arterial influx, on the other hand, can lead to collapse of the fistula, which can often be caused by hypotension, spasm of the vessel, needle or coagulated access, bending of the arterial line (influx), and the use of needles with a gauge incompatible with blood flow. Literature indicates needle repositioning in these cases, as it may be attached to the vessel wall(12).

Dressing should be carried out with light compression with gauze for approximately five minutes. Then, tape and gauze are used when hemostasis is complete, paying attention to compression, because studies have shown that there have been cases of patients who lost access after dressing with excessive compression ${ }^{(15)}$.

The CVI obtained in the items of AVF complications monitoring and prevention protocol was unsatisfactory in only one of them. It described the practice of turning the needle bevel down to a CVI of 0.63 . As previously described, there is no systematic study of such conduct. The other items presented satisfactory indices, with a variation from 0.81 to 1.0 , corroborating what the literature analyzed for this study recommends.

AVF complications monitoring and prevention is currently one of the main strategies that should be instituted by health facilities in response to the challenge of improving the quality of dialysis offered for as long as possible with greater preservation of the vascular access network ${ }^{(8,17)}$.

Health institutions should also provide in-service training plans to organize and make information available to nurses. This will enable them to develop their scientific and technical capacities for assisting people with AVF. These training plans foster comprehensive nursing care $^{(8,12)}$.

With the development of these programs, nurses can acquire cognitive skills and develop skills. In addition, they can identify complications that may compromise vascular access and how to act on them, as well as promote the teaching of care to their staff in order to cooperate and contribute to patient safety ${ }^{(18-19)}$. In addition, both the Guidelines for Vascular Access and the European Renal Association - European Dialysis and Transplant Association emphasize and recommend the teaching of self-care to patients ${ }^{(19)}$.

\section{Study limitations}

Among the limitations found in this research, there is a restriction on the search for articles available for free, which may have caused a limitation on the number of references used. In 
addition, all participating judges belong to the same city and hospital, which may have restricted their view and assessment of the protocol.

\section{Contributions to nursing, health or public policy}

We hope that the elaborated protocol can contribute to the systematization of autonomous nursing interventions. Thus, it could contribute to the development of cognitive and behavioral skills that enable nurses, in dialysis units, to be able to effectively and skillfully assess and interpret the objective and subjective data of AVF. The availability of this guide also contributes to safe care with high emphasis on the role of nurse examiner.

\section{CONCLUSIONS}

Literature analysis of nursing care with vascular access enabled the development of a tool aimed at caring for the person with AVF integrating concepts that relate to each other, whose objectives relate to AVF complications monitoring and prevention. CVI showed agreement among the participating judges, ensuring relevance of the constructed content, as well as its application in care.

\section{REFERENCES}

1. Sociedade Brasileira de Nefrologia. Censo da Sociedade Brasileira de Nefrologia [Internet]. 2017[cited 2018 Jun 08]. Available from: http:// www.sbn.org.br

2. Dos Anjos MD, Oselame GB. Cuidados de enfermagem para pacientes idosos com fístula arteriovenosa em terapia de hemodiálise. Rev UNIANDRADE [Internet]. 2013[cited 2018 Jun 08];14(3):251-62. Available from: https://www.uniandrade.br/revistauniandrade/index.php/ revistauniandrade/article/view/80

3. Alfonso SM, Cruz DO, Cona YM, González BN. Aneurisma de fístula arteriovenosa para hemodiálisis. Rev Cuba Ci [Internet]. 2013[cited 2018 Jun 08];52(3)211-7. Available from: http://scielo.sld.cu/scielo.php?script=sci_arttext\&pid=S0034-74932013000300006

4. Ministério da Saúde (BR). Portaria no 1.675, de 7 de junho de 2018. Brasília (DF); 2018.

5. Alexandre NMC, Coluci MZO. Validade de conteúdo nos processos de construção e adaptação de instrumento e medidas. Ciênc Saúde Coletiva.;16(7):3061-8. doi: 10.1590/S1413-81232011000800006

6. Mendes KDS, Silveira RCCP, Galvão CM. Revisão Integrativa: método de pesquisa para incorporação de evidências na saúde e na enfermagem. Texto Contexto Enferm. 2008;17(4):758-64. doi: 10.1590/S0104-07072008000400018

7. Polit DF, Beck CT. Fundamentos da pesquisa em enfermagem: avaliação de evidências para a prática de enfermagem. $9^{a}$ ed. Porto Alegre: ArtMed; 2019.

8. Sousa CN. Cuidar da pessoa com fístula arteriovenosa: modelo para a melhoria contínua. Rev Port Saúde Pública. 2012;30(1):11-17. doi: 10.1016/j.rpsp.2011.11.001.

9. Asif A, Leon C, Orozco-Vargas LC, Krishnamurthy G, Choi KL, Mercado C, et al. Accuracy of physical examination in the detection of arteriovenous graft stenosis. Semin Dial. 2008;21:85-88. doi: 10.1111/j.1525-139X.2007.00382.x

10. Beathard GA. An algorithm for the physical examination of early fistula failure. Semin Dial. 2015;18:331-335. doi: 10.1111/j.1525-139X.2005.18314.X

11. Sousa CN, Apóstolo JL, Figueiredo MH, Martins MM, Dias VF. Physical examination: how to examine the arm with arteriovenous fistula. Hemodialysis Int. 2013;17:300-6. doi: 10.1111/j.1542-4758.2012.00714.x

12. Medina IMF. Cuidados de la Fístula Arteriovenosa durante la sesión de Hemodiálisis. ENE-Rev Enferm. 2013;7(1). Available from: http://eneenfermeria.org/ojs/index.php/ENE/article/view/199

13. Toregeani JF, Kimura CJ, Rocha AST, Volpiani GG, Bortoncello A, Shirasu K, et. al. Avaliação da maturação das fístulas arteriovenosas para hemodiálise pelo eco-Doppler colorido. J Vasc Bras. 2008;7(3). doi: 10.1590/S1677-54492008000300005

14. Santos I, Rocha RPF, Berardinelli LMM. Necessidades de orientação de enfermagem para o autocuidado de clientes em terapia de hemodiálise. Rev Bras Enferm. 2011;64(2):335-42. doi: 10.1590/S0034-71672011000200018

15. Silva KA, Nunes ZB. As intervenções de enfermagem mais prevalentes em um serviço de hemodiálise frente às intercorrências com a fístula arteriovenosa durante a sessão de hemodiálise. J Health Sci Inst [Internet]. 2011 [cited 2018 Jun 08];29(2):110-3. Available from: https:// pesquisa.bvsalud.org/portal/resource/pt/lil-606306

16. Paiva TRS, Lima FET. Manutenção das fístulas arteriovenosas confeccionadas no Centro de Nefrologia de Caucaia-CE. Rev Min Enferm [Internet]. 2008[cited 2018 Jun 08];12(3):313-20. Available from: http://www.reme.org.br/artigo/detalhes/271

17. Huber TS, Larive B, Imrey PB, Radeva MK, Kaufman JM, Kraiss LW, et al. Access related hand ischemia and the hemodialysis fistula maturation study. J Vasc Surg. 2016;64(4):1050-8. doi: 10.1016/j.jvs.2016.03.449

18. Ishani A, Gilbertson DT, Kim D, Bradbury BD, Collins AJ. Predialysis care and dialysis outcomes in hemodialysis patients with a functioning fistula. Am J Nephrol. 2014;39:238-47. doi: 10.1159/000358843

19. Woo K, Goldman DP, Romley JA. Early Failure of Dialysis Access among the Elderly in the Era of Fistula First. Clin J Am Soc Nephrol. 2015; 10:1791-98. doi:10.2215/CJN.09040914 